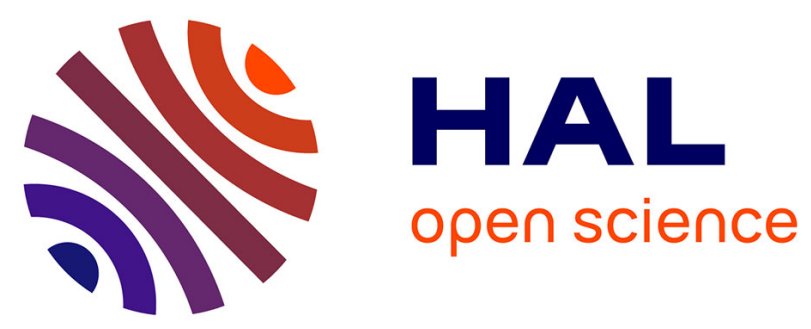

\title{
Neutron microtomography-based virtual extraction and analysis of a cercopithecoid partial cranium (STS 1039) embedded in a breccia fragment from sterkfontein member 4 (South Africa)
}

Amélie Beaudet, José Braga, Frikkie de Beer, Burkhard Schillinger, Christine Steininger, Vladimira Vodopivec, Clément Zanolli

\section{To cite this version:}

Amélie Beaudet, José Braga, Frikkie de Beer, Burkhard Schillinger, Christine Steininger, et al.. Neutron microtomography-based virtual extraction and analysis of a cercopithecoid partial cranium (STS 1039) embedded in a breccia fragment from sterkfontein member 4 (South Africa). American Journal of Physical Anthropology, 2016, 159 (4), pp.737-745. 10.1002/ajpa.22916 . hal-02296649

\section{HAL Id: hal-02296649 \\ https://hal.science/hal-02296649}

Submitted on 26 Feb 2021

HAL is a multi-disciplinary open access archive for the deposit and dissemination of scientific research documents, whether they are published or not. The documents may come from teaching and research institutions in France or abroad, or from public or private research centers.
L'archive ouverte pluridisciplinaire HAL, est destinée au dépôt et à la diffusion de documents scientifiques de niveau recherche, publiés ou non, émanant des établissements d'enseignement et de recherche français ou étrangers, des laboratoires publics ou privés. 


\title{
Neutron microtomography-based virtual extraction and analysis of a cercopithecoid partial cranium (STS 1039) embedded in a breccia fragment from sterkfontein member 4 (South Africa)
}

Amélie Beaudet, José Braga, Frikkie de Beer, Burkhard Schillinger, Christine Steininger, Vladimira Vodopivec, Clément Zanolli

\begin{abstract}
The Plio-Pleistocene karstic sedimentary deposits of Sterkfontein Cave, South Africa, yielded numerous fossil primate specimens embedded in blocks of indurated breccia, including the partial cercopithecoid cranium labelled STS 1039. Because the surrounding matrix masks most of its morphology, the specimen remains taxonomically undetermined. While the use of X-ray microtomography did not allow extracting any structural information about the specimen, we experimented a new investigative technique based on neutron microtomography. Using this innovative approach, we successfully virtually extracted, reconstructed in 3D and quantitatively assessed the preserved dentognathic structural morphology of STS 1039, including details of its postcanine maxillary dentition. Following comparative analyses with a number of PlioPleistocene and extant cercopithecoid taxa, we tentatively propose a taxonomic attribution to the taxon Cercopithecoides williamsi. Our experience highlights the remarkable potential of this novel imaging method to extract diagnostic information and to identify the fossil remains embedded in hard breccia from the South African hominin-bearing cave sites.
\end{abstract}

\author{
Abbreviations \\ AST-RX : Accès Scientifique à la Tomographie à Rayons-X \\ CIRIMAT : Centre Inter-Universitaire de Recherche et d'Ingénierie des Matériaux \\ EDJ : Enamel-dentine junction \\ FERMaT :Fluides Energie Réacteurs Matériaux et Transferts \\ GM: Geometric morphometric \\ MD: Mesiodistal
}

The Plio-Pleistocene karstic complex site of Sterkfontein (Gauteng Province, South Africa) is known for having yielded numerous australopithecine remains, as well as chronologically younger evidence of early Homo (e.g., Broom and Schepers, 1946; Broom et al., 1950; Tobias, 1965; Clarke and Tobias, 1995; Moggi-Cecchi et al., 2006). The hominin-bearing units also delivered 
more cercopithecoid remains than any other fossiliferous site in South Africa (Heaton, 2006). As yet, six papionin taxa (Parapapio jonesi,Pp. whitei,Pp. broomi, Papio izodi, P. robinsoni, Theropithecus oswaldi) and one colobine (Cercopithecoides williamsi) were recovered in its deposits (Delson, 1984, 1988; Pickering et al., 2004; Heaton, 2006).

Among the primate assemblages from Sterkfontein, Brain (1981: 205) mentioned a monkey cranial fragment labelled STS 1039 and preliminarily assigned it to Cercopithecoidea indet. Heaton (2006: 440) provided a first anatomical description of this incomplete fossil specimen based on the meagre tooth evidence appreciable at the external surface of the breccia. However, as STS 1039 is embedded in a block of sedimentary breccia which masks most details of its morphology (Fig. 1A), no detailed study of this material has been performed so far and its taxonomic attribution remains uncertain. In order to reveal the presence of any possible diagnostic element preserved in the hardened sediment, we preliminary detailed the breccia block by using X-ray microtomography. However, due to the extremely low contrast between "container" (the breccia) and "content" (bony and tooth elements), the record failed to provide reliable information of taxonomic value. Accordingly, we tentatively experienced the use of advanced investigative techniques based on neutron microtomography $(\mathrm{n}-\mu \mathrm{CT})$, whose absorption profile (interaction mechanism of neutrons with matter) differs from X-rays because of the unique ability of neutrons to penetrate materials opaque to X-rays and by being more strongly attenuated by the organic material (Kardjilov et al., 2003; Winkler, 2006; Sutton, 2008; Tremsin et al., 2015). 

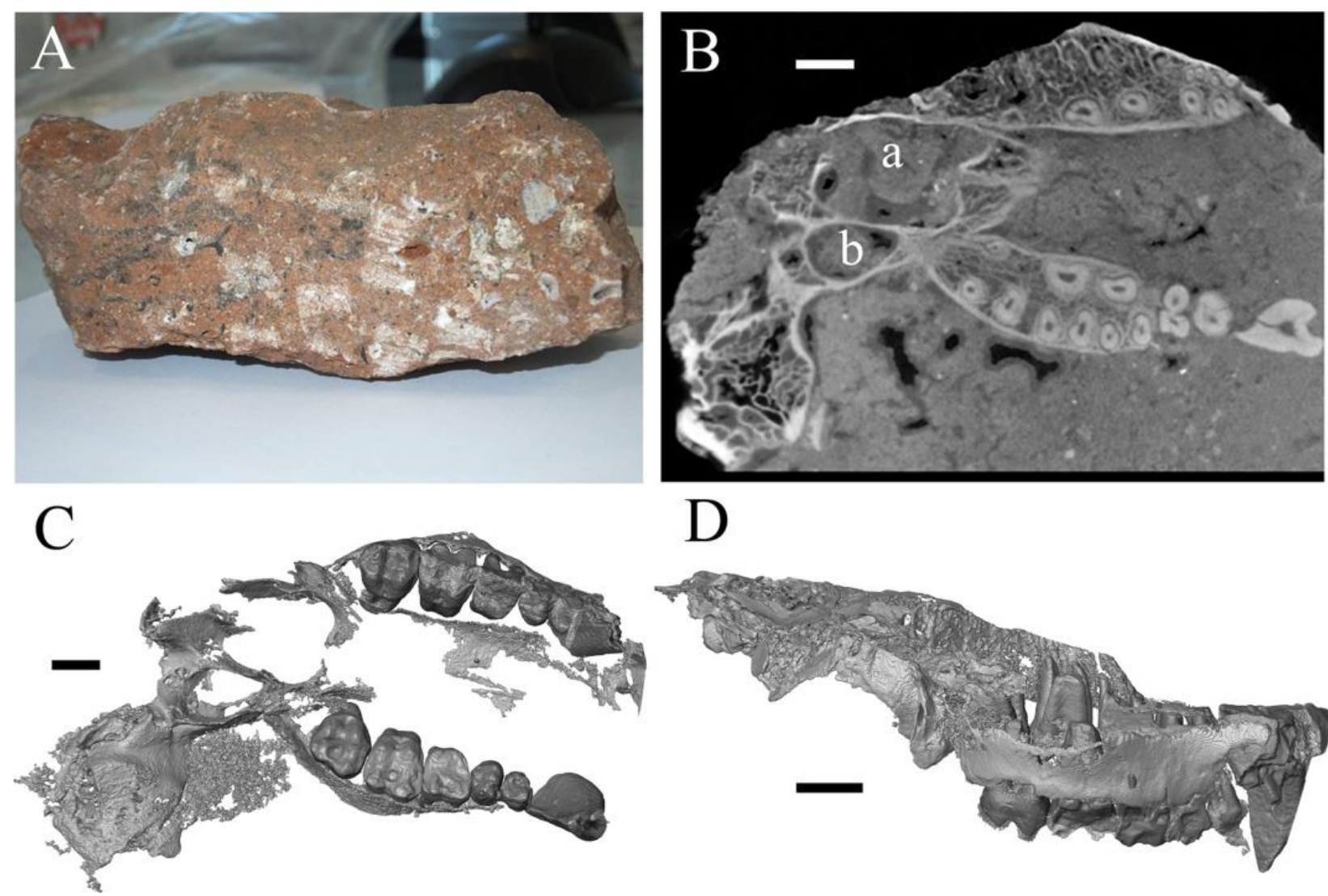

$\mathrm{D}$

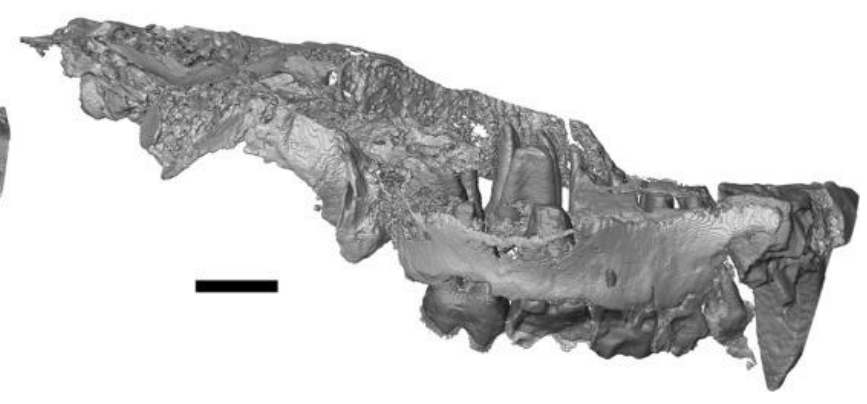

Figure 1. The block of sedimentary breccia from Sterkfontein embedding the specimen STS 1039 (A). Virtual slice of the breccia (B) by neutron microtomography $(n-\mu C T)$ showing the quality of the signal and the preservation state of the specimen, notably of the nasal cavity (a) and of the pterygoid fossa (b). The 3D reconstruction of the virtually extracted maxilla is shown in occlusal (C) and right lateral (D) views. Scale bars: $1 \mathrm{~cm}$.

\section{MATERIALS AND METHODS}

$\mathrm{X}$-rays tube microfocus and synchrotron radiations contrasts between materials are attenuated due to the different natural absorption and scattering (e.g., Pair-production or Compton scattering principles) of X-rays and to the different electron cloud densities surrounding the atoms of the analyzed materials (thus depending of the element positions in the periodic system). Since the neutrons are only being absorbed or scattered by the nucleus of the atom, this principle does not apply to neutron-based analyses. The neutrons only interact directly with the nuclei of the atoms as being neutral particles, delivering contrast depending on the inner structure of the nuclei which often shows huge differences between neighbouring elements, and even between isotopes of the same element (Kardjilov et al., 2003; Winkler, 2006; Tremsin et al., 2015). Hydrogen is a special 
case, which attenuates neutron beams by equal-mass scattering, while heavier mineral elements, usually constituting geological and paleontological material, are easily penetrated and additionally show high contrast levels between bone and matrix (breccias) (Schwarz et al., 2005; Sutton, 2008). In summary, neutron radiography and $n-\mu \mathrm{CT}$ are bound to deliver contrast very different from Xrays, sometimes even complementary (Sutton, 2008). In this study, neutrons help to distinguish between the otherwise very similar dense materials representing the matrix, maxillary bone, tooth enamel and dentine.

The block of breccia bearing the partial cranium STS 1039 (c. $13.5 \times 7 \times 3 \mathrm{~cm}$ ) is permanently stored at the Ditsong National Museum of Natural History, Pretoria, South Africa. In 2014, the specimen has been detailed by $\mathrm{n}-\mu \mathrm{CT}$ at the ANTARES Imaging facility (SR4a beamline) of the Heinz Maier-Leibnitz Center (FRM II) of Technische Universität München, Germany. The measurements were carried out according to the following parameters: the neutron beam originated from the cold source of the FRM II reactor, with an energy range mostly from 3 to $20 \mathrm{meV}$, a collimation ratio of $\mathrm{L} / \mathrm{D}=500$ (ratio between sample-detector distance and collimator aperture) and an intensity of $6.4 \times 10^{7} \mathrm{n} / \mathrm{cm}^{2} \mathrm{~s}$. The final virtual volume was reconstructed with an isotropic voxel size of 75.0 $\mu \mathrm{m}$. Because the detection of the tissue interfaces is based on attenuation at the boundary of a structure in both X-ray and neutron-based microtomography, we performed a threshold-based segmentation with manual corrections (Spoor et al., 1993), as usually applied for X-ray acquisitions using the software Avizo v.7.0 (Visualization Sciences Group Inc.).

In order to compare STS 1039 to the reference dimensional record provided by Freedman (1957) for the fossil Cercopithecoidea crania of South Africa, we measured the distance between the lateral surfaces of the maxillae anteriorly to the third premolar (meas. BP3) and anteriorly to the third molar (meas. BM3).

Following segmentation, the elements of each tooth row have been isolated and virtually extracted for visualization and quantitative assessment of their structural features (Figs. 1C,D and 2). Besides the outer mesiodistal (MD) and buccolingual (BLm and BLd) crown diameters of the upper left M1 and M2 and of the right M3, a total of six linear, surface and volumetric variables describing internal tooth crown structure and tissue proportions were digitally measured or calculated on the unsmoothed virtual surfaces of the upper right M3, the best preserved tooth element of STS 1039 (Table 1). Before assessing their crown size, we virtually integrated the punctually damaged lateral 
enamel of both left M1 and M2. Intra- and inter-observer tests for measurement accuracy run by two observers revealed differences less than 5\% (cf. Bondioli et al., 2010; Zanolli et al., 2014).

Table 1. Linear, surface and volumetric variables used for assessing external and internal tooth structural variation and tissue proportions

\begin{tabular}{|c|c|c|}
\hline Variables & Definition & Unit \\
\hline MD & Crown mesiodistal diameter & $\mathrm{mm}$ \\
\hline BLm & Crown trigon buccolingual diameter & $\mathrm{mm}$ \\
\hline BLd & Crown talon buccolingual diameter & $\mathrm{mm}$ \\
\hline Ve & Volume of the enamel cap & $\mathrm{mm}^{3}$ \\
\hline Vcdp & Volume of the coronal dentine and pulp & $\mathrm{mm}^{3}$ \\
\hline Vc & Total crown volume, including enamel, dentine and pulp & $\mathrm{mm}^{3}$ \\
\hline SEDJ & Enamel-dentine junction surface & $\mathrm{mm}^{2}$ \\
\hline 3D $\operatorname{AET}(=V e / S E D J)$ & Average enamel thickness & $\mathrm{mm}$ \\
\hline $\begin{array}{l}\text { 3D } \\
\left(=3 \mathrm{DAET} /\left(\mathrm{Vcdp}^{1 / 3}\right)^{*} 100\right)\end{array}$ & $\begin{array}{l}\text { Scale-free three-dimensional relative enamel thickness } \\
\text { (Kono, 2004; Olejniczak et al., 2008) }\end{array}$ & \\
\hline
\end{tabular}

Enamel thickness topographic distribution in the upper third molar was rendered at the outer enamel surface through a 3D map (where thickness increases from "thin" dark blue to "thick" red), which facilitates the site-specific and synthetic comparative assessment of this complex variable (Macchiarelli et al., 2008, 2013; Bayle et al., 2011).

A comparative geometric morphometric (GM) analysis of the enamel-dentine junction (EDJ) of the right M3 was performed on the reconstructed virtual surface by placing six sets of 3D semilandmarks along the marginal ridges and transverse crests connecting the mesiolingual and mesiobuccal and the distolingual and distobuccal cusps, respectively, representing a total of 88 points (Skinner et al., 2008). A between-group principal component analysis (bgPCA) was 
performed to examine overall shape variation of both the extant and fossil samples, and the taxonomically undetermined specimen STS 1039 was thus projected onto the shape space to identify its closest neighbours (Mitteroecker and Bookstein, 2011).

For comparative purposes, we used information from the literature and the original high resolution X-ray microtomographic record of a number of Plio-Pleistocene South African and extant cercopithecoid specimens representing a whole of 9 taxa (Table 2). The fossil sample has been detailed by microtomography at the South African Nuclear Energy Corporation (Necsa), Pretoria, and at the Palaeosciences Centre in the University of the Witwatersrand, Johannesburg. Extant specimens were imaged at the platform Accès Scientifique à la Tomographie à Rayons-X (ASTRX), Paris, and using the equipment provided by the French Research Federation Fluides Energie Réacteurs Matériaux et Transferts (FERMaT) available at the Centre Inter-Universitaire de Recherche et d'Ingénierie des Matériaux (CIRIMAT), Toulouse.

Table 2. List of the Plio-Pleistocene and extant cercopithecoid specimens/samples detailed by Xray microtomography $(\mu \mathrm{CT})$ and used for comparatively assessing external and internal maxillary morphology and tooth structural variation and tissue proportions

\begin{tabular}{|c|c|c|c|c|c|c|c|c|c|}
\hline Specimen/Sample & & Site/Provenance & Description & Stored at & References & $\begin{array}{l}\mu \mathrm{CT} \text { acquisition } \\
\text { voxel size }(\mu \mathrm{m})\end{array}$ & $\begin{array}{l}\text { Tissue } \\
\text { proportions }\end{array}$ & $\begin{array}{l}\text { Enamel } \\
\text { maps }\end{array}$ & EDJ \\
\hline \multicolumn{10}{|l|}{ Fossil taxa (genus abbrev.) } \\
\hline \multirow[t]{2}{*}{ Parapapio (Pp.) broomi } & STS 544 & $\begin{array}{l}\text { Sterkfontein } \\
\text { (Member 4) }\end{array}$ & Maxilla & Ditsong $^{\mathrm{a}}$ & $\begin{array}{l}\text { Eisenhart, 1974; } \\
\text { Heaton, } 2006\end{array}$ & 50.2 & $\mathrm{X}$ & $\mathrm{X}$ & $\mathrm{X}$ \\
\hline & MP 224 & Makapansgat & $\begin{array}{l}\text { Female } \\
\text { cranium }\end{array}$ & Wits $^{b}$ & $\begin{array}{l}\text { Freedman, 1976; } \\
\text { Jablonski, } 2002\end{array}$ & 81.6 & $\mathrm{X}$ & & $\mathrm{X}$ \\
\hline Parapapio (Pp.) whitei & MP 221 & Makapansgat & $\begin{array}{l}\text { Male } \\
\text { cranium }\end{array}$ & Wits $^{b}$ & $\begin{array}{l}\text { Freedman, 1976; } \\
\text { Gilbert, } 2013\end{array}$ & 71.2 & & $\mathrm{X}$ & $\mathrm{X}$ \\
\hline Parapapio (Pp.) jonesi & STS 565 & $\begin{array}{l}\text { Sterkfontein } \\
\text { (Member 4) }\end{array}$ & $\begin{array}{l}\text { Female } \\
\text { cranium }\end{array}$ & Ditsong $^{\mathrm{a}}$ & $\begin{array}{l}\text { Freedman, 1957; } \\
\text { Eisenhart, 1974; } \\
\text { Heaton, } 2006\end{array}$ & 71.9 & & $\mathrm{X}$ & \\
\hline Papio (P.) angusticeps & KA 194 & Kromdraai A & $\begin{array}{l}\text { female } \\
\text { cranium }\end{array}$ & Ditsonga & $\begin{array}{l}\text { Freedman, 1957; } \\
\text { Gilbert, } 2013\end{array}$ & 74.0 & & $\mathrm{X}$ & $\mathrm{X}$ \\
\hline
\end{tabular}




\begin{tabular}{|c|c|c|c|c|c|c|c|c|c|}
\hline \multicolumn{2}{|l|}{ Specimen/Sample } & Site/Provenance & Description & Stored at & References & $\begin{array}{l}\mu \mathrm{CT} \text { acquisition } \\
\text { voxel size }(\mu \mathrm{m})\end{array}$ & $\begin{array}{l}\text { Tissue } \\
\text { proportions }\end{array}$ & $\begin{array}{l}\text { Enamel } \\
\text { maps }\end{array}$ & EDJ \\
\hline \multirow[t]{2}{*}{ Papio $(P$.$) robinsoni$} & SK 555 & $\begin{array}{l}\text { Swartkrans } \\
\text { (Member 1) }\end{array}$ & $\begin{array}{l}\text { Male } \\
\text { muzzle }\end{array}$ & $\begin{array}{l}\text { Ditsong } \\
\text { a }\end{array}$ & $\begin{array}{l}\text { Freedman, 1957; } \\
\text { Jablonski, } 2002\end{array}$ & 77.5 & & & $\mathrm{X}$ \\
\hline & SK 602 & $\begin{array}{l}\text { Swartkrans } \\
\text { (Member 1) }\end{array}$ & $\begin{array}{l}\text { Male } \\
\text { maxilla }\end{array}$ & $\begin{array}{l}\text { Ditsong } \\
\mathrm{a}\end{array}$ & Freedman, 1957 & 86.6 & $\mathrm{X}$ & $\mathrm{X}$ & $\mathrm{X}$ \\
\hline $\begin{array}{l}\text { Gorgopithecus (G.) maj } \\
\text { or }\end{array}$ & KA 192 & Kromdraai A & $\begin{array}{l}\text { Male } \\
\text { cranium }\end{array}$ & $\begin{array}{l}\text { Ditsong } \\
\text { a }\end{array}$ & $\begin{array}{l}\text { Freedman, 1957; } \\
\text { Jablonski, 2002; } \\
\text { Gilbert, } 2013\end{array}$ & 63.6 & & $\mathrm{X}$ & $\mathrm{X}$ \\
\hline $\begin{array}{l}\text { Cercopithecoides }(C .) w \\
\text { illiamsi }\end{array}$ & M 3055 & Makapansgat & $\begin{array}{l}\text { Male } \\
\text { cranium }\end{array}$ & Witsb & $\begin{array}{l}\text { Maier, 1970; } \\
\text { Jablonski, } 2002\end{array}$ & 78.7 & $X$ & $X$ & $\mathrm{X}$ \\
\hline \multicolumn{10}{|l|}{ Extant taxa (genus abbrev.) } \\
\hline Papio (P.) sp. & & $\begin{array}{l}\text { Ethiopia, } \\
\text { Zambia, } \\
\text { Central } \\
\text { African } \\
\text { Republic, } \\
\text { Congo }\end{array}$ & $\begin{array}{l}\text { Male } \\
\& \\
\text { female } \\
\text { crania }\end{array}$ & $\begin{array}{l}\text { MNHNc } \\
\text { RMCAd }\end{array}$ & & $32.7-104.5$ & 4 & 1 & 6 \\
\hline $\begin{array}{l}\text { Colobus (Col.) } \quad n=3 \\
\text { sp. }\end{array}$ & & Congo & $\begin{array}{l}\text { Male } \\
\& \\
\text { female } \\
\text { crania }\end{array}$ & $\begin{array}{l}\text { MNHNc } \\
\text { RMCAd }\end{array}$ & & $32.7-66.2$ & 2 & 1 & 3 \\
\hline
\end{tabular}

For each variable (tissue proportions, enamel distribution maps and EDJ morphology), the fossil specimens that were used are notified by "X", while the number of individuals is given for the extant groups.

${ }^{a}$ Ditsong National Museum of Natural History, Pretoria.

${ }^{b}$ University of the Witwatersrand, Johannesburg.

${ }^{c}$ Muséum national d'Histoire naturelle, Paris.

${ }^{d}$ Royal Museum for Central Africa, Tervuren.

\section{RESULTS}

The specimen preserves both maxillary bones, the pterygoid bones and part of the left temporal bone, including the mastoid process and the external acoustic meatus, up to the level of the canine 
jugum (Fig. 1B). Even if only partially preserved, the maxilla apparently lacks the maxillary fossa extending from P3 to M3 commonly seen in Papio and suggests instead a relatively flat and smooth outline. The presence of a maxillary sinus, a structure usually found above the postcanine tooth roots in living macaques and fossil colobines (Kuykendall and Rae, 2008; Rae, 2008), cannot be assessed in STS 1039 because of incomplete preservation (Fig. 1B). The maximal external breadth across the maxillae measured anterior to the P3s (BP3) and to the M3s (BM3) corresponds to 37.5 $\mathrm{mm}$ and $45.7 \mathrm{~mm}$, respectively (Table 3). For both BP3 and BM3 cross-sectional breadths, STS 1039 nears the condition expressed by $P p$. jonesi and $C$. williamsi from Sterkfontein and $P p$. antiquus from Taung. Conversely, in terms of absolute values and proportions, STS 1039 differs from both the larger G. major from Kromdraai A and D. ingens from Swartkrans, but better approximates the condition of extant $P$. ursinus males.

Table 3. Dimensions (in $\mathrm{mm}$ ) of the maxillary breadth measured anterior to the $\mathrm{P} 3$ and to the $\mathrm{M} 3$ in STS 1039 and in some Plio-Pleistocene and extant cercopithecoid specimens/samples

\begin{tabular}{|c|c|c|c|c|c|c|}
\hline Taxon & Origin & $n$ & $\mathrm{BP} 3 \mathrm{a}$ & s.d. & $n$ & $\mathrm{BM} 3 \mathrm{~b}$ \\
\hline STS 1039 & STSc & & 37.5 & & & 45.7 \\
\hline Pp. broomi & STSc, MPh & 3 & 41.3 & & 2 & 49.5 \\
\hline Pp. jonesi & STSc & 2 & 37 & & 2 & 47 \\
\hline Pp. antiquus & TGe & 1 & 36 & & 3 & 48.3 \\
\hline P. izodi & $\mathrm{TGe}$ & & & & 3 & 44.7 \\
\hline P. robinsoni & SKd & 6 & 46 & 8.3 & 4 & 53.3 \\
\hline P. angusticeps & $\mathrm{COg}, \mathrm{KAf}$ & 2 & 41.5 & & 2 & 46 \\
\hline D. ingens & SKd & 2 & 48 & & 1 & 53 \\
\hline G. major & KAf & 2 & 47.5 & & 1 & 54 \\
\hline C. williamsi & STSc, MPh & 2 & 34.5 & & 2 & 42 \\
\hline
\end{tabular}




\begin{tabular}{|lccccccc|}
\hline Taxon & Origin & $n$ & BP3a & s.d. & $n$ & BM3b & s.d. \\
P. ursinus $\mathrm{M}$ & extant & 35 & 54 & 2.3 & 35 & 56 & 3.3 \\
P. ursinus F & extant & 7 & 41 & 2.0 & 7 & 50 & 1.3 \\
\hline
\end{tabular}

See Table 2 for the meaning of the genera abbreviations.

${ }^{a}$ Distance between the lateral surfaces of the maxillae anterior to P3

${ }^{b}$ Distance between the lateral surfaces of the maxillae anterior to M3

${ }^{c}$ Sterkfontein

${ }^{d}$ Swartkrans

${ }^{e}$ Taung

${ }^{f}$ Kromdraai A

${ }^{g}$ Cooper's

${ }^{h}$ Makapansgat; male; M, male; F, female. All comparative data are from Freedman (1957).

Together with the relatively complete elements of the right and left upper postcanine dentition, the crown of the left maxillary canine and a small root fragment of the right canine are also preserved (Fig. 1C,D). Because of some occlusal wear having slightly affected both third molars (stage 1B; Delson, 1973) and the completely developed roots, STS 1039 certainly represents an adult, more likely a young adult individual.

On comparative ground, the minimal estimate of the well-preserved left canine crown height (25.3 mm; Fig. 2A) is compatible with the South African male cercopithecoid condition reported by Freedman (1957). 


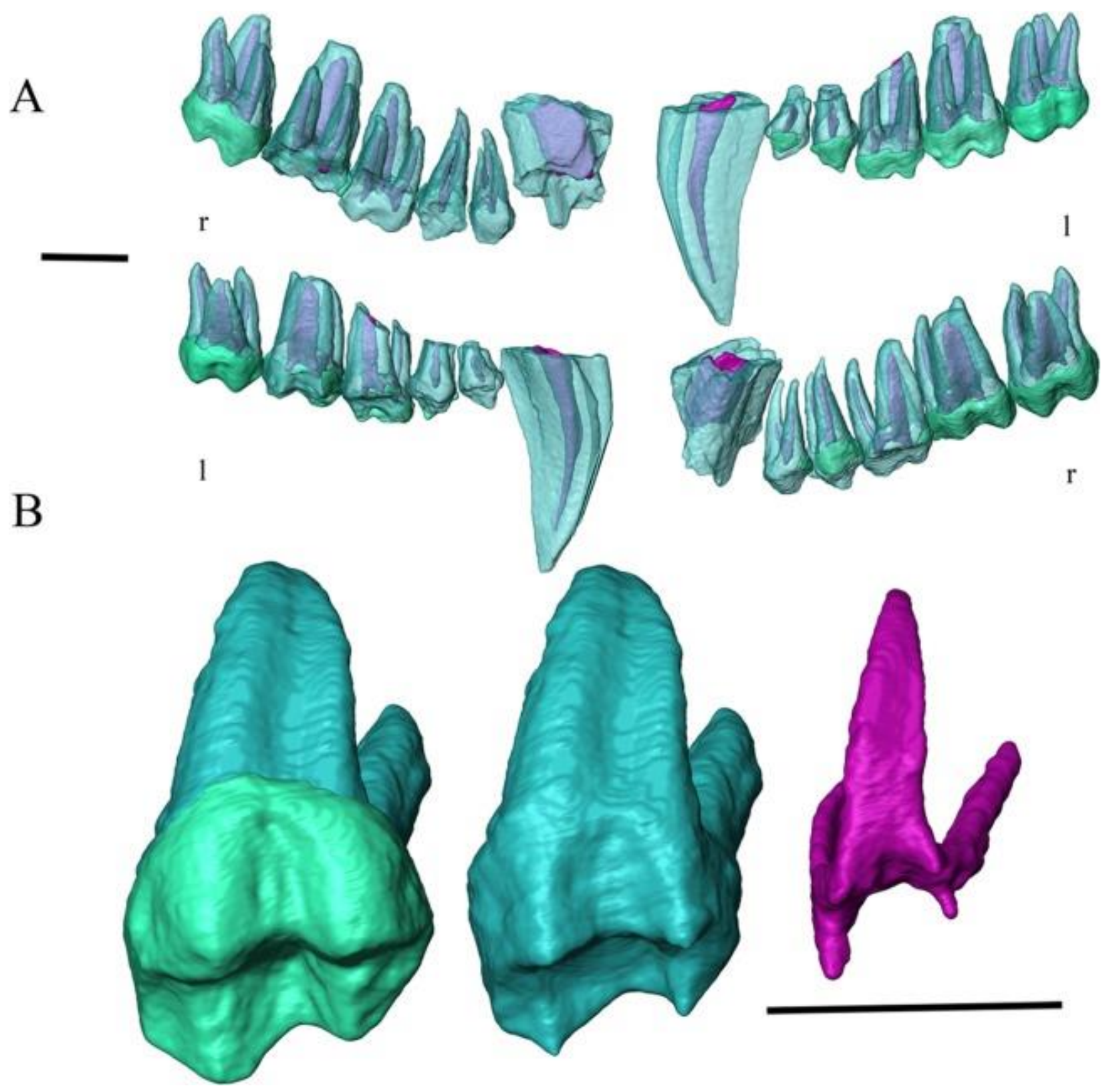

Figure 2. (A) The virtually extracted right (r) and left (1) tooth rows of STS 1039 rendered in semitransparency in buccal (upper) and lingual view (lower). (B) 3D rendering of the upper RM3 showing the outer enamel and dentine (left), the enamel-dentine junction (centre), and the pulp cavity (right) in occluso-lingual view. Scale bars: $1 \mathrm{~cm}$.

The third and fourth premolar, as well as the first molar crowns are damaged, most of their enamel being lost. While the roots of the left post-canine teeth are perfectly preserved, those of the right raw, from the third premolar to second molar, are broken (Fig. 2A,B). The postcanine dentition of STS 1039 significantly differs from the high-crowned and columnar-cusped specialized cheek teeth 
of Theropithecus (Jolly, 1972; Jablonski, 2002; Jablonski and Frost, 2010). Conversely, STS 1039 molar morphology is consistent with $C$. williamsi, especially by displaying a marked lingual median notch, and both South African fossil Papio and Parapapio taxa, which share flared crowns bearing relatively low bulbous cusps (Freedman, 1957; Szalay and Delson, 1979; Jablonski, 2002). The assessed crown dimensions of the left M1 and M2 (following virtual integration of the missing enamel), as well as of the right M3 of STS 1039 are shown in the Table 4 and comparative analyses are illustrated in the Figure 3. In this comparative context, the molar dimensions of STS 1039 globally fit the proportions displayed by fossil Pp. broomi, Pp. jonesi, P. izodi and C. williamsi, and that of extant $P$. cynocephalus.

A
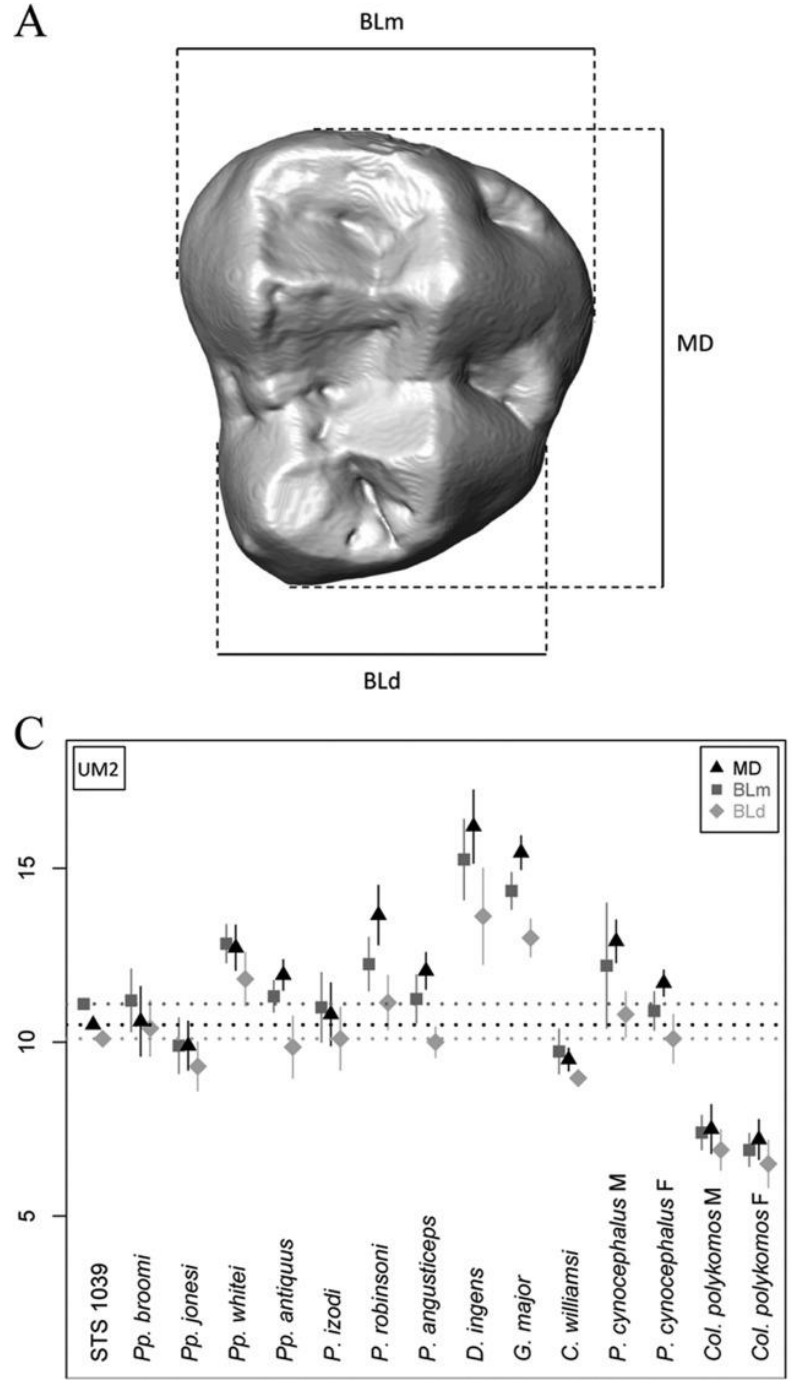

$\mathrm{B}$

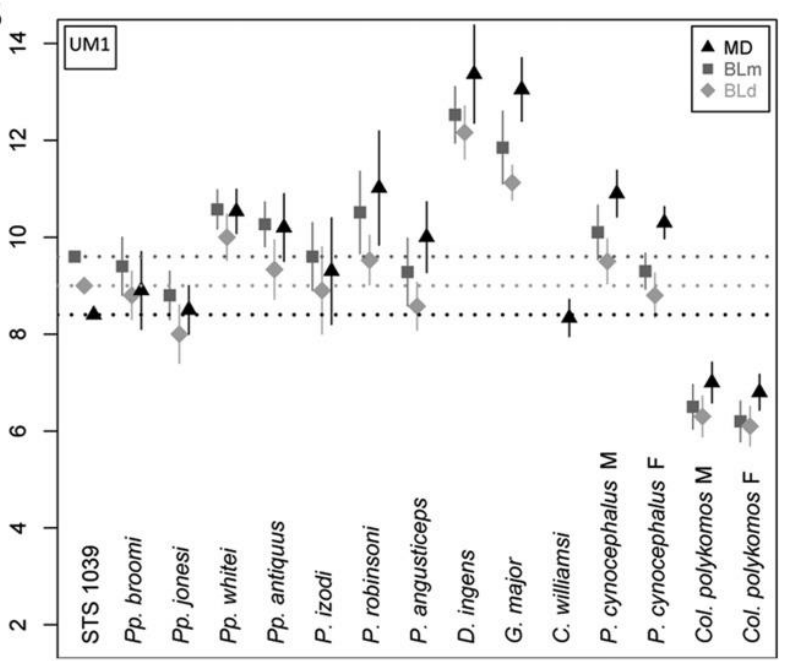

D

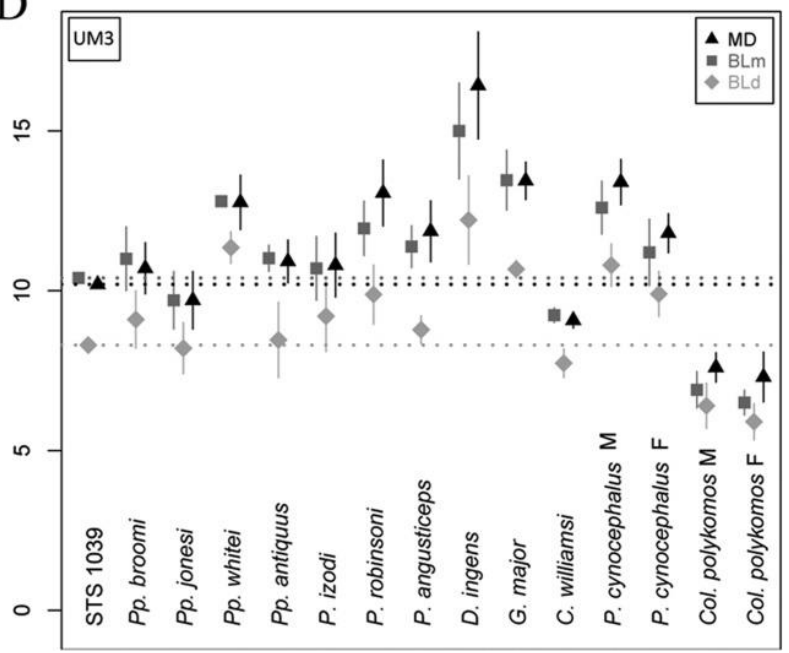

Figure 3. (A) Occlusal surface model of an extant Papio upper M3 showing the crown length (MD diameter) and mesial (mBL) and distal (dBL) breadths. (B-D) Plots of the crown dimensions (in 
$\mathrm{mm}$ ) of the upper M1 (B), M2 (C) and M3 (D) measured in STS 1039 and in some Plio-Pleistocene and extant ( $P$. cynocephalus and Col. polykomos) cercopithecoid samples. The dotted lines represent the STS 1039 projected values. See Table 2 for the meaning of the genera abbreviations. M, male; F, female. Comparative data sources: statistics for Parapapio broomi, Pp. jonesi and $P$. izodi from Sterkfontein are from Heaton (2006); Pp. whitei (STS 259-263-303-336-343-370B389B-462) from Sterkfontein, Pp. antiquus (AD 943, CT 5356, T 10-16-17-20-25, Tv 639) from Taung, $P$. robinsoni (CO 134D, SK 25-436-439-444-456-458-465-476-479-484-485-497-499500-503-508-509-529-531-536-537-538-540-544-555-557-558-560-562-565-566-571B-576-582587-590-592-602-608-613-614-623) and $D$. ingens (SB 3, SK 440-441-443-473-487-498-513542-545-546-548-553-574-577-578-585-593-600-603-604-630) from Swartkrans, Skurweberg and Cooper's, $P$. angusticeps (KA 156-157-161-174-194, CO 100-102-105-117-137) from Kromdraai A and Cooper's, G. major (KA 153-154-170-178-182-192-193), from Kromdraai A and $C$. williamsi (AD 1326, M 631-655A-666, STS 252-350-347-361-392-394A, T 15) from Sterkfontein, Taung and Makapansgat are from Freedman (1957); statistics for extant $P$. cynocephalus and Col. polykomos are from Swindler (2002).

Table 4. Crown length (MD diameter) and mesial (mBL) and distal (dBL) breadths (in mm) of the upper LM1, LM2 and RM3 measured in STS 1039

\begin{tabular}{|lccc|}
\hline & MD & BLm & BLd \\
\hline ULM1 & 8.4 & 9.6 & 9.0 \\
ULM2 & 10.5 & 11.1 & 10.1 \\
URM3 & 10.2 & 10.4 & 8.3 \\
\hline
\end{tabular}

The tissue proportions were quantified in unworn crowns available in our comparative sample (Table 2). Compared with Parapapio broomi, P. robinsoni, C. williamsi and extant Papio sp. the M3 of STS 1039 shows the lowest values for the total volume of the enamel cap (Ve) and the volume of the coronal dentine and pulp (Vcdp) (Table 5), but significantly exceeds the estimates available for Colobus. In terms of both relative (RET) and average (AET) enamel thickness, STS 
1039 closely approximates the pattern displayed by $C$. williamsi in showing a relatively thinenamel (Table 5).

Table 5. Crown tissue proportions (including average and relative enamel thickness) of the M3 in STS 1039 (right side) and in some Plio-Pleistocene and extant cercopithecoid specimens/samples

\begin{tabular}{|c|c|c|c|c|c|c|c|}
\hline Taxon (specimen) & $\mathrm{Ve}\left(\mathrm{mm}^{3}\right)$ & $\begin{array}{l}\text { Vcdp } \\
\left(\mathrm{mm}^{3}\right)\end{array}$ & $\mathrm{Vc}\left(\mathrm{mm}^{3}\right)$ & $\begin{array}{l}\text { SEDJ } \\
\left(\mathrm{mm}^{2}\right)\end{array}$ & $\begin{array}{l}3 \mathrm{D} \\
(\mathrm{mm})\end{array}$ & AET & 3D RET \\
\hline STS 1039 & 119.1 & 189.2 & 308.3 & 165.7 & 0.7 & & 12.5 \\
\hline Pp. broomi (STS 544) & 191.8 & 238.0 & 429.8 & 215.0 & 0.9 & & 14.4 \\
\hline Pp. broomi (MP 224) & 248.2 & 254.7 & 502.9 & 218.1 & 1.1 & & 18.0 \\
\hline P. robinsoni $(\mathrm{SK} 602)$ & 343.2 & 447.0 & 790.3 & 321.2 & 1.1 & & 14.0 \\
\hline C. williamsi (M 3055) & 129.9 & 196.3 & 326.2 & 177.6 & 0.7 & & 12.6 \\
\hline$P$. sp. mean $(n=4)$ & 232.4 & 237.2 & 469.7 & 205.9 & 1.1 & & 18.2 \\
\hline $\min$ & 163.6 & 159.0 & 322.6 & 167.4 & 1.0 & & 17.3 \\
\hline $\max$ & 285.4 & 281.0 & 566.4 & 231.5 & 1.2 & & 18.8 \\
\hline Col. sp. $(n=2)$ & 49.8 & 58.0 & 107.8 & 81.1 & 0.6 & & 16.0 \\
\hline $\min$. & 49.5 & 52.5 & 102.0 & 74.7 & 0.6 & & 14.3 \\
\hline $\max$ & 50.1 & 63.5 & 113.5 & 87.6 & 0.7 & & 17.7 \\
\hline
\end{tabular}

See Table 1 for the meaning of the variables and Table 2 for the genera abbreviations.

The cartographies imaging enamel thickness distribution across the overall M3 crowns projected in different perspectives in STS 1039 and selected comparative specimens are presented in Figure 4. STS 1039 clearly reveals relatively thin enamel across the entire crown, the thickest areas being located on the buccal cusp apices and along the buccal marginal ridge. The $C$. 
williamsi specimen represents the closest fit, while Papio, Parapapio and Gorgopithecus species exhibit much thicker lateral enamel.

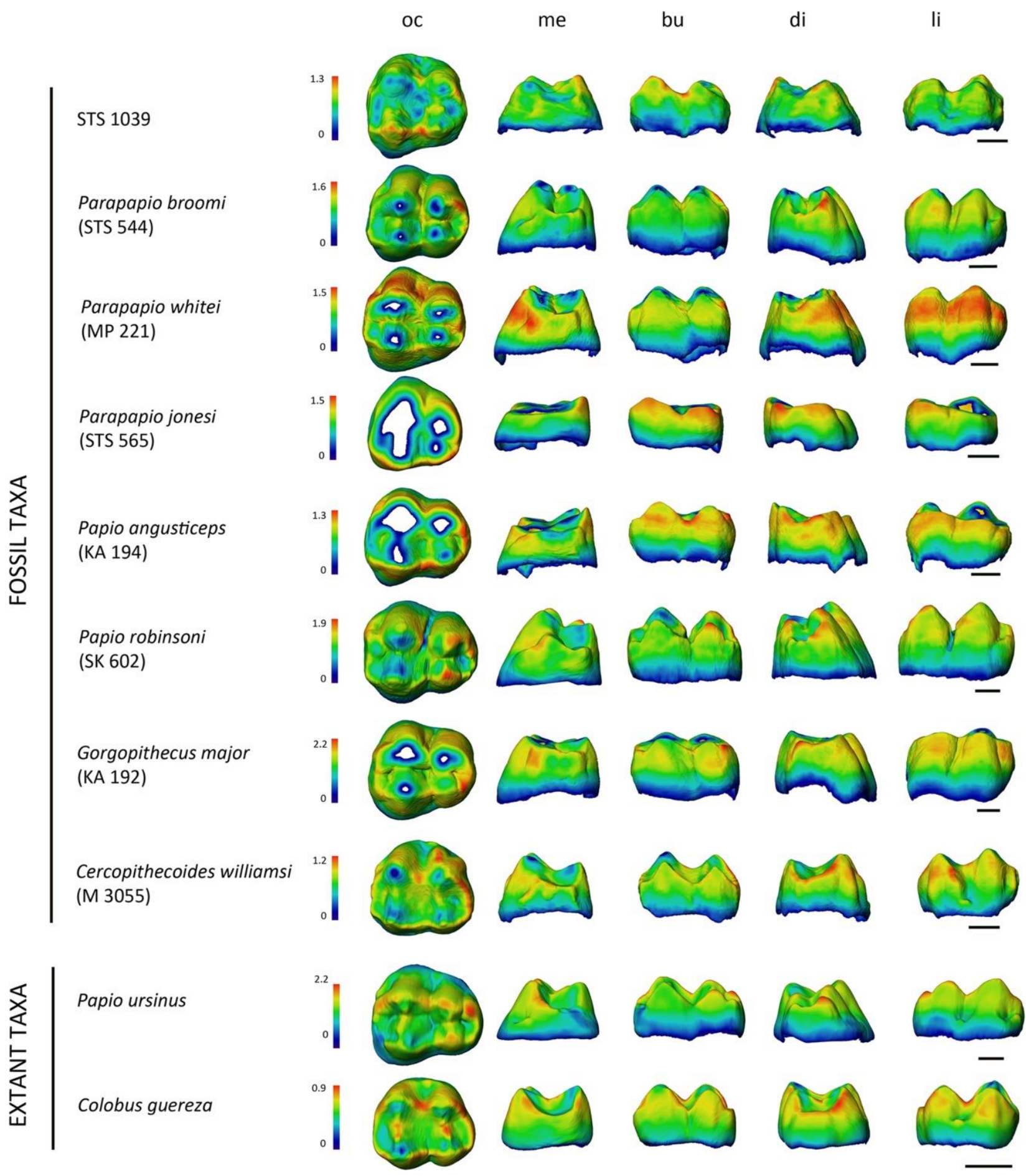

Figure 4. Enamel thickness (mm) cartographies of the upper RM3 crown of STS 1039 compared with the condition revealed by some selected Plio-Pleistocene and extant (P. ursinus and Col. 
guereza) cercopithecoid specimens. Topographic thickness variation is rendered by a pseudocolour scale ranging from thinner dark-blue to thicker red; isolated spots correspond to enamel removal following wear. Independently from their original side, all crowns are shown as right and imaged in occlusal (oc), mesial (me) buccal (bu), distal (di), and lingual (li) views. See Table 2 for information about the fossil specimens. Scale bars: $3 \mathrm{~mm}$.

The results of the between-group principal component analysis (bgPCA) shown in Figure 5 based on the third molar EDJ Procrustes shape coordinates of STS 1039 and 17 comparative specimens are shown in Figure 5. The first component of the bgPCA distinguishes the buccolingually wide occlusal basin of STS 1039, C. williamsi and Colobus sp. (in the negative space of bgPC1) from the straighter condition seen in the group constituted by fossil Parapapio species and P. robinsoni, as well as from the larger fossil papionin G. major (mostly located in the positive space of bgPC1). Along bgPC2, mainly influenced by the position of the mesial cusps, STS 1039 again approximates the condition shown by Colobus sp. and C. williamsi, as well as, to a lesser extent, of Papio sp. 


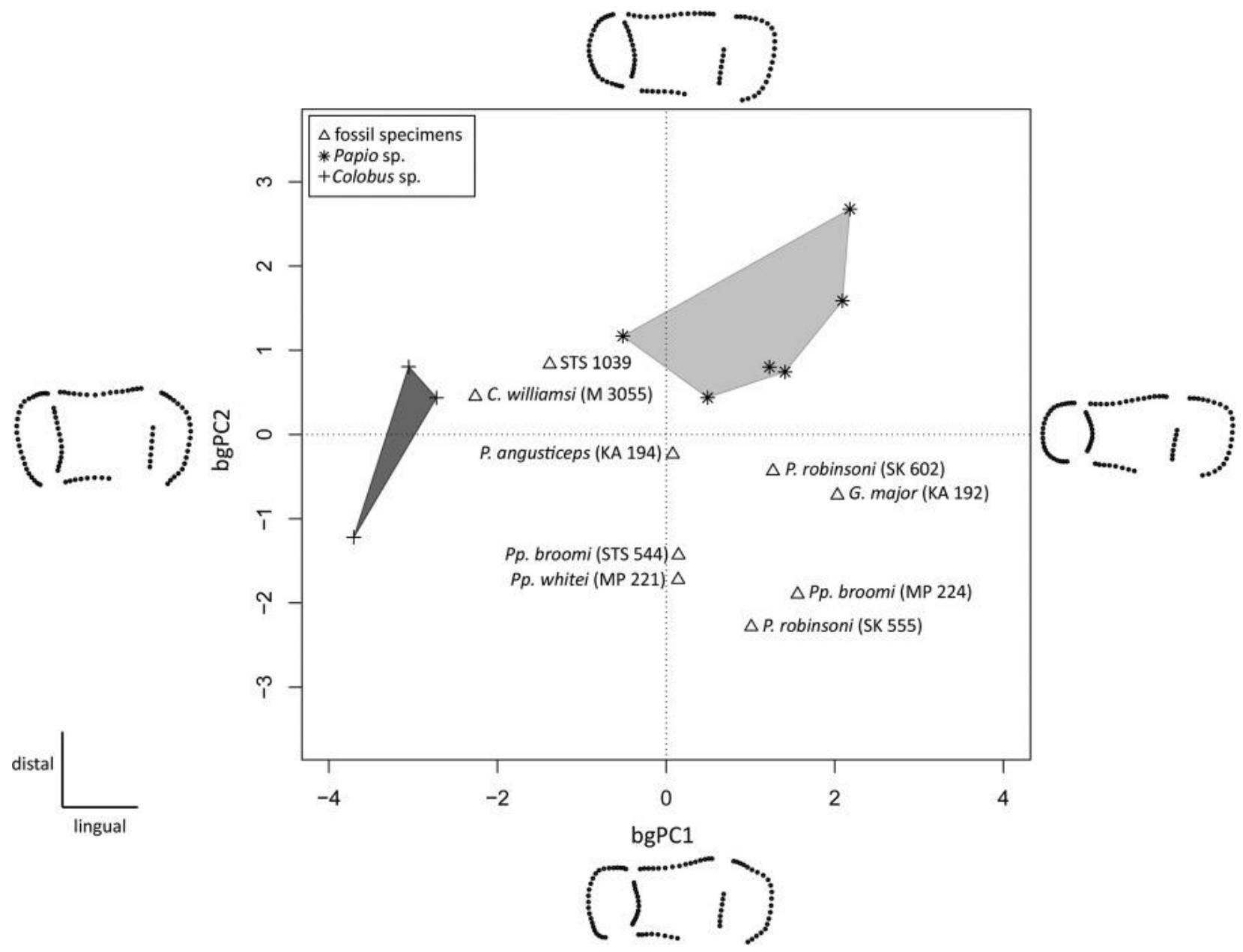

Figure 5. Between-group principal component analysis (bgPCA) of the Procrustes-registered shape coordinates of the EDJ morphology calculated for the upper RM3 of STS 1039 compared with the evidence from some Plio-Pleistocene and extant (Papio sp. and Col. sp.) specimens. The shapes at the extremities of the axes illustrate the morphological variation trends along each component. The light and dark grey convex hulls represent the variability expressed by modern Papio and Colobus, respectively.

\section{DISCUSSION}

Based on the set of morphological, dimensional and structural dentognathic features specifically considered in this study, we note that STS 1039 shows affinities in terms of molar crown dimensions, enamel thickness and EDJ morphology with the fossil species Cercopithecoides williamsi. At this stage, pending the availability of larger comparative Plio-Pleistocene cercopithecoid virtual records to perform similar analyses, the most parsimonious decision is to temporarily attribute this specimen to the extinct colobine taxon $C$. williamsi. 
The use of advanced radiography techniques based on neutron microtomography ( $\mathrm{n}-\mu \mathrm{CT})$ to inspect the breccia block embedding the partial monkey cranium from Sterkfontein proved to be successful. So far, $\mathrm{n}-\mu \mathrm{CT}$ has been used to detail some vertebrate fossil specimens (Schwarz et al., 2005; Grellet-Tinner et al., 2011) and to tentatively discriminate between enamel and dentine in highly mineralized hominid teeth (Zanolli et al., 2013). However, at the best of our knowledge, this is the first time such highly promising analytical approach is applied to virtually disclose and 3D render the content of breccified primate remains from the South African hominin-bearing cave sites. Our experience with STS 1039 illustrates a potentially novel approach to solving the problems commonly encountered in such contexts, where as much of paleontological work centres on physically removing fossils from breccia blocks, a delicate and time-consuming activity which is not systematically free from the risk of damaging the embedded specimens. Before deciding, case by case, for any physical/chemical extraction - a decision which, anyhow, essentially relies on the specific research questions (Schwarz et al., 2005) - we note the ability of $n-\mu C T$ in providing an immediate accurate picture of the whole elements contained in the blocks and in revealing sources of data previously impossible to access (e.g., bone morphology, enamel thickness across the crown, EDJ shape, etc.).

Accordingly, it is likely that advances in $\mathrm{n}-\mu \mathrm{CT}$ technology will allow in a near future the extensive investigation of a variety of paleontological remains, including notably for the abundant South African hominin specimens embedded in breccia, for which laboratory X-ray analyses cannot grant the extraction of reliable structural information.

\section{ACKNOWLEDGMENTS}

The authors are indebted to S. Potze (Pretoria), B. Zipfel (Johannesburg), J. Cuisin (Paris), G. Fleury (Toulouse), E. Gilissen and W. Wendelen (Tervuren) for having granted access to fossil and comparative material under their care. They also thank K. Carlson and T. Jashashvili (Johannesburg), L. Bam and J. Hoffman (Pretoria), G. Clément and M. Garcia-Sanz (Paris), C. Tenailleau and B. Duployer (Toulouse) for micro-X-ray tomographic acquisitions, J. Dumoncel and D. Ginibriere (Toulouse) for methodological support and contribution to data processing. For scientific discussion, they are especially grateful to E. Delson (New York), N. Jablonski (University Park), R. Macchiarelli (Poitiers and Paris), and F. Thackeray (Johannesburg). They thank two anonymous reviewers for their valuable comments that improved the quality of the 
paper. The French research federation FERMaT (FR3089), the National Research Foundation (NRF) and Department of Science and Technology (DST) of South Africa are acknowledged for providing access to micro- $\mathrm{X}$-ray tomography facilities.

\section{REFERENCES}

Bayle P, Bondioli L, Macchiarelli R, Mazurier A, Puymerail L, Volpato V, Zanolli C. 2011. Three-dimensional imaging and quantitative characterization of human fossil remains. Examples from the NESPOS database. In: R Macchiarelli, GC Weniger, editors. Pleistocene databases. Acquisition, storing, sharing. Wissenschaftliche Schriften des Neanderthal Museums 4. p 29-46.

Bondioli L, Bayle P, Dean MC, Mazurier A, Puymerail L, Ruff C, Stock JT, Volpato V, Zanolli C, Macchiarelli R. 2010. Morphometric maps of long bone shafts and dental roots for imaging topographic thickness variation. Am J Phys Anthropol 142: 328-334.

Brain CK. 1981. The hunters of the hunted? An introduction to African cave taphonomy. Chicago: University of Chicago Press.

Broom R, Schepers GWH. 1946. The South African fossil ape-men: the Australopithecinae. Transv Mus Mem 2.

Broom R, Robinson JT, Schepers GWH. 1950. Sterkfontein ape-man Plesianthropus. Transv Mus Mem 4.

Clarke RJ, Tobias PV. 1995. Sterkfontein Member 2 foot bones of the oldest South African hominid. Science 269: 521-524.

Delson E. 1973. Fossil colobine monkeys of the Circum-Mediterranean region and the evolutionary history of the Cercopithecidae (Primates, Mammalia), PhD dissertation, New York: Columbia University.

Delson E. 1984. Cercopithecoid biochronology of the African Plio-Pleistocene: correlation among eastern and southern hominid-bearing localities. Cour Forsch Inst Senckenberg 69: 199-281.

Delson E. 1988. Chronology of South African australopiths site units. In: FE Grine, editor. Evolutionary history of the 'robust' australopithecines. New York: Aldine de Gruyter. p 317324.

Eisenhart WL. 1974. The fossil cercopithecoids of Makapansgat and Sterkfontein, AB Thesis, Cambridge: Harvard College.

Freedman L. 1957. The fossil Cercopithecoidea of South Africa. Ann Transv Mus 23: 121-262.

Freedman L. 1976. South African fossil Cercopithecoidea: a re-assessment including a description of new material from Makapansgat, Sterkfontein and Taung. J Hum E 5: 297-315. 
Gilbert CC. 2013. Cladistic analysis of extant and fossil African papionins using craniodental data. J Hum E 64: 399-433.

Grellet-Tinner G, Sim CM, Kim DH, Trimby P, Higa A, An SL, Oh HS, Kim T, Kardjilov N. 2011. Description of the first lithostrotian titanosaur embryo in ovo with Neutron characterization and implications for lithostrotian Aptian migration and dispersion. Gondwana Res 20: 621-629.

Heaton JL. 2006. Taxonomy of the Sterkfontein fossil Cercopithecinae: the Papionini of Members 2 and 4 (Gauteng, South Africa), PhD dissertation, Indiana: Indiana University.

Jablonski NG, 2002. Fossil Old World monkeys: the late Neogene radiation. In: W Hartwig, editor. The primate fossil record. Cambridge: Cambridge University Press. p 255-299.

Jablonski NG, Frost S. 2010. Cercopithecoidea. In: L Werdelin, WJ Sanders, editors. Cenozoic mammals of Africa. Berkeley: University of California Press. p 393-428.

Jolly CJ. 1972. The classification and natural history of Theropithecus (Simopithecus) (Andrews, 1916), baboons of the African Plio-Pleistocene. Bull Br Mus Nat Hist Geol 22: 1-123.

Kardjilov N, Baechler S, Bastürk M, Dierick M, Jolie J, Lehmann E, Materna T, Schillinger B, Vontobel P. 2003. New features in cold neutron radiography and tomography. Part II: applied energy-selective neutron radiography and tomography. Nucl Instr Meth Phys Res A 501: 536-546.

Kono R. 2004. Molar enamel thickness and distribution patterns in extant great apes and humans: new insights based on a 3-dimensional whole crown perspective. Anthrop Sci 112: 121-146.

Kuykendall KL, Rae TC. 2008. Presence of the maxillary sinus in fossil Colobinae (Cercopithecoides williamsi) from South Africa. Anat Rec 291: 1499-1505.

Macchiarelli R, Bayle P, Bondioli L, Mazurier A, Zanolli C. 2013. From outer to inner structural morphology in dental anthropology. The integration of the third dimension in the visualization and quantitative analysis of fossil remains. In: GR Scott, JD Irish, editors. Anthropological perspectives on tooth morphology. Genetics, evolution, variation. Cambridge: Cambridge University Press. p 250-277.

Macchiarelli R, Bondioli L, Mazurier A. 2008. Virtual dentitions: touching the hidden evidence. In: JD Irish, GC Nelson, editors. Technique and application in dental anthropology. Cambridge: Cambridge University Press. p 426-448.

Maier W. 1970. New fossil Cercopithecoidea from the lower Pleistocene cave deposits of the Makapansgat Limeworks, South Africa: Palaeont Afr 13: 69-107.

Mitteroecker P, Bookstein F. 2011. Linear discrimination, ordination, and the visualization of selection gradients in modern morphometrics. Evol Biol 38: 100-114. 
Moggi-Cecchi J, Grine FE, Tobias PV. 2006. Early hominid dental remains from Members 4 and 5 of the Sterkfontein Formation (1966 - 1996 excavations): catalogue, individual associations, morphological descriptions and initial metrical analysis. J Hum E 50: 239-328.

Olejniczak AJ, Smith TM, Feeney RNM, Macchiarelli R, Mazurier A, Bondioli L, Rosas A, Fortea J, de la Rasilla M, Garcia-Tabernero A, Radovčić J, Skinner MM, Toussaint M, Hublin JJ. 2008. Dental tissue proportions and enamel thickness in Neandertal and modern human molars. J Hum E 55: 12-23.

Pickering TR, Clarke RJ, Heaton JL. 2004. The context of Stw 573, an early hominid skull and skeleton from Sterkfontein Member 2: taphonomy and paleoenvironment. J Hum E 46: 279297.

Rae TC. 2008. Paranasal pneumatization in extant and fossil Cercopithcoidea. J Hum E 54: 279286.

Schwarz D, Vontobel P, Lehmann EH, Meyer CA, Bongartz G. 2005. Neutron tomography of internal structures of vertebrate remains: a comparison with $\mathrm{X}$-ray computed tomography. Palaeont Electron 8. Available at: http://palaeo-electronica.org/2005_2/neutron/issue2_05.htm.

Skinner MM, Gunz P, Wood BA, Hublin JJ. 2008. Enamel-dentine junction (EDJ) morphology distinguishes the lower molar molars of Australopithecus africanus and Paranthropus robustus. J Hum E 55: 979-988.

Spoor CF, Zonneveld FW, Macho GA. 1993. Linear measurements of cortical bone and dental enamel by computed tomography: applications and problems. Am J Phys Anthropol 91: 469484.

Sutton MD. 2008. Tomographic techniques for the study of exceptionally preserved fossils. Proc R Soc B 275: 1587-1593.

Swindler DR. 2002. Primate dentition. An introduction to the teeth of non-human primates. Cambridge: Cambridge University Press.

Szalay FS, Delson E. 1979. Evolutionary history of the primates. New York: Academic Press.

Tobias PV. 1965. Australopithecus, Homo habilis, tool-using and tool-making. S Afr Archaeol Bull 20: 167-192.

Tremsin AS, Morgano M, Panzner T, Lehmann E, Filgers U, Vallerga JV, McPhate JB, Siegmund OHW, Feller WB. 2015. High resolution neutron imaging capabilities at BOA beamline at Paul Scherrer Institut. Nucl Instr Meth Phys Res A 784: 486-493.

Winkler B. 2006. Applications of neutron radiography and neutron tomography. Rev Min Geochem 63: 459-471.

Zanolli C, Bondioli L, Coppa A, Dean MC, Bayle P, Candilio F, Capuani S, Dreossi D, Fiore I, Frayer DW, Libsekal Y, Mancini L, Rook L, Medin Tekle T, Tuniz C, Macchiarelli R. 2014. 
The late Early Pleistocene human dental remains from Uadi Aalad and Mulhuli-Amo (Buia), Eritrean Danakil: macromorphology and microstructure. J Hum E 74: 96-113.

Zanolli C, Mancini L, Kullmer O, Macchiarelli R, Rook L, Schillinger B, Schrenk F, Tuniz C, Vodopivec V. 2013. Problems and limitations of X-ray microtomography for the endostructural characterization of fossil tooth tissues. Munich: 1st Int Conf Neutron Imaging and Neutron Methods in Archaeology. 